\title{
RP2 wt Allele
}

National Cancer Institute

\section{Source}

National Cancer Institute. RP2 wt Allele. NCI Thesaurus. Code C75566.

Human RP2 wild-type allele is located within Xp11.4-Xp11.21 and is approximately $45 \mathrm{~kb}$ in length. This allele, which encodes protein XRP2, plays a role in photoreceptor development. Mutations in this gene are associated with X-linked mental retardation with retinitis pigmentosa. 